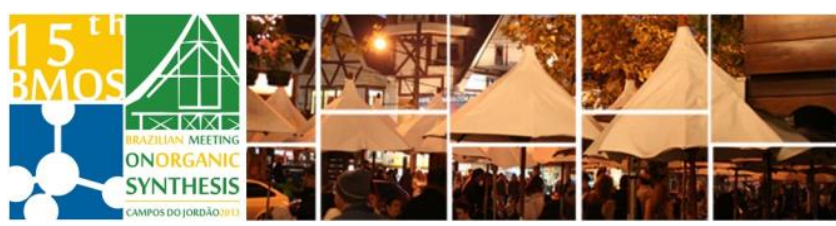

\title{
Synthesis of some 1,2,3-triazole-chalcones as potential anticancer agents
}

\author{
Jaqueline C. Pessôa ${ }^{1}$ (PG), Pãmella C. O. de Oliveira ${ }^{1}$ (IC), Meliza J. da C. Fonseca \\ (IC) ${ }^{1}$, Sergio Pinheiro ${ }^{1}(P Q)$, Estela M. F. Muri ${ }^{2}(P Q)$, Ayres G. Dias ${ }^{3}(P Q)$ and Paulo R. \\ R. $\operatorname{Costa}^{4}(P Q)$.
}

1-IQ, UFF 2- Faculdade de Farmácia, UFF 3- IQ, UERJ 4- NPPN, UFRJ.

*jaqueline_cavalcanti@yahoo.com.br

Keywords: chalcone, 1,2,3-triazole, anticancer

\section{INTRODUCTION}

Chalcones constitute an important class of natural products belonging to the flavonoids family that display several biological activities. ${ }^{1}$ In this context, chalcones received significant attention for their anti-tumor properties which are often associated to inhibition of polymerization of tubulins in the site of colchicine binding. ${ }^{1}$ Triazoles constitute an important class of heterocycles because of their varied biological activities and being regarded as an interesting unit with significant anticancer profile in many of the human cell lines. ${ }^{2-4}$ The recent discovery that some 1,2,3-triazole chalcones possess high citotoxicities against some cancer cell lines ${ }^{5,6}$ encouraged us to the access of structurally simple chalcones possessing the 1,2,3-triazole core as potential anticancer agents.

\section{RESULTS AND DISCUSSION}

The 1,2,3-triazole chalcones 1a-i were prepared in moderate yields by the Claisen-Schmidt condensation $^{7}$ of the appropriated acetophenones 2a-i with the known ${ }^{8}$ aldehyde 3 in presence of aqueous alkaline base (Scheme 1).

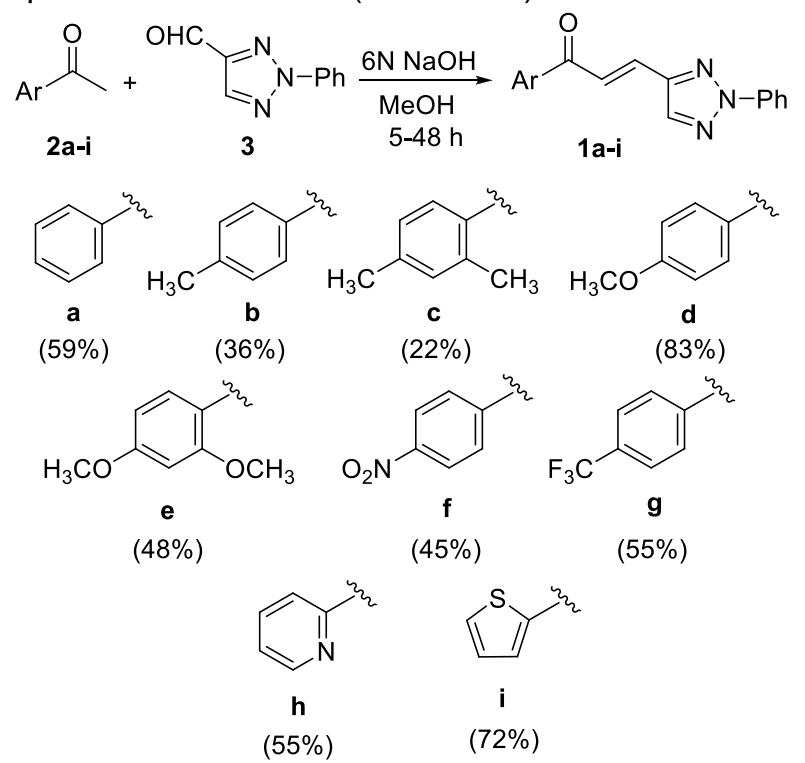

All yields of chalcones 1a-i were obtained after recrystalization in methyl alcohol or in ethyl alcohol. The 1,2,3-triazole chalcones $\mathbf{1 a}, \mathbf{1 b}$ and $\mathbf{1 d}$ are already known in the literature and the yields of 1a and $\mathbf{1 b}$ were somewhat lower than described.9,10 These results suggest that the presence of either donor or withdrawing substituents in the acetophenones have no correlation with the yields of the novel chalcones $1 \mathrm{c}$ and $1 \mathrm{e}-\mathrm{i}$.

\section{CONCLUSION}

The Claisen-Schmidt reaction of acetophenones with the aldehyde 3 led to several 1,2,3-triazolechalcones 1a-i with potential anticancer activity. The biological evaluation of these compounds against several cancer cell lines is under progress.

\section{ACKNOWLEDGEMENTS}

The authors are thankful to FAPERJ, CNPq and CAPES for fellowship and the financial support.

\section{REFERENCES}

${ }^{1}$ Dyrager, C.; Wickström, M.; Fridén-Saxin, M.; Friberg, A.; Dahlén, K.; Wallén, E. A. A.; Gullbo, J.; Grøtli, M.; Luthman, K. Bioorg. Med. Chem. 2011, 19, 2659.

${ }^{2}$ Kamal, A.; Shankaraiah, N.; Devaiah, V.; Laxma Reddy, K.; Juvekar, A.; Sen, S.; Kurianb, N.; Zingdeb, S. Bioorg. Med. Chem. Lett. 2008, 18, 1468.

${ }^{3}$ Wang, M.; Xia, Y.; Fan, Y.; Rocchi, P.; Qu, F.; lovanna, J. L.; Peng, L. Bioorg. Med. Chem. Lett. 2010, 20, 5979.

${ }^{4}$ He, R.; Chen, Y.; Chen, Y.; Ougolkov, A. V.; Zhang, J. S.; Savoy, D. N.; Billadeau, D. D.; Kozikowski, A. P. J. Med. Chem. 2010, 53, 1347.

${ }^{5}$ Singh, P.; Raj, R.; Kumar, V.; Mahajan, M. P.; Bedi, P. M. S.; Kaur, T.; Saxena, A., K., Eur. J. Med. Chem. 2012, 47, 594 and references cited.

${ }^{6}$ Kamal, A.; Prabhakar, S.; Ramaiah, M. J.; Reddy, P. V.; Reddy, Ch. R.; Mallareddy, A.; Shankaraiah, N.; Reddy, T. L. N.; Pushpavalli, S. N. C. V. L.; Pal-Bhadra, M. Eur. J. Med. Chem. 2011, 46, 3820.

${ }^{7}$ Bakó,T.; Bakó. P.; Keglevich, G.; Báthori, N.; Czugler, M.; Tatai, J.; Novák, T.; Parlagh, G.; Töke, L., Tetrahedron: Asymmetry. 2003, 14, 1917.

8 Silva Júnior, R. C.; Ferreira, V. F.; Pinheiro, F. Tetrahedron: Asymmetry 2004, 15, 3719 .

9 Fang, L.; Zheng-Feng, X.; Fang-Ming, L. Chem. J. Chinese Universities. 2006, 27, 1058.

${ }^{10}$ Hui, Y. H.; Chen, C. M.; Xie, Z. F. Chinese Chem. Lett. 2012, 23, 525 .

Scheme 1. Synthesis of the chalcones 1a-i.

$15^{\text {th }}$ Brazilian Meeting on Organic Synthesis - 15 $5^{\text {th }}$ BMOS - November10-13, 2013 - Campos do Jordão, Brazil 